\title{
Studies of the changes in systemic copper metabolism and excretion produced by the intravenous administration of trithiomolybdate in sheep
}

\author{
BY J. MASON ${ }^{1}$, M. LAMAND 2 , J. C. TRESSOL ${ }^{2}$ AND G. MULRYAN \\ ${ }^{1}$ Biochemistry Department, Trinity College, Dublin 2, Irish Republic \\ ${ }^{2}$ Laboratoire des Maladies Nutritionnelles, INRA, CRZV de Theix 63122, Ceyrat, France
}

(Received 5 May 1987 - Accepted 23 September 1987)

1. The effects of intravenous trithiomolybdate administration on the fate of ${ }^{64} \mathrm{Cu}$ and on stable Cu metabolism were examined in sheep held in metabolism cages and fed on a low-Cu diet supplying $2.95 \mathrm{mg} \mathrm{Cu} /$ animal per d.

2. In Expt 1 the injection of trithiomolybdate, $30 \mathrm{mg}$ molybdenum/sheep per $\mathrm{d}$ for $5 \mathrm{~d}$, greatly increased plasma $\mathrm{Cu}$ levels and more than doubled the faecal $\mathrm{Cu}$ excretion. Urinary $\mathrm{Cu}$ excretion was unaffected. The disappearance from plasma of ${ }^{64} \mathrm{Cu}$ injected during the trithiomolybdate administration was slowed although faecal ${ }^{64} \mathrm{Cu}$ excretion was increased more than threefold.

3. In Expt 2 trithiomolybdate, 10 and $30 \mathrm{mg} \mathrm{Mo/sheep} \mathrm{per} \mathrm{d}$ for $3 \mathrm{~d}$, was administered $22 \mathrm{~h}$ after the injection of ${ }^{64} \mathrm{Cu}$. Radioactivity reappeared immediately in plasma and faecal ${ }^{64} \mathrm{Cu}$ excretion was increased.

4. In both experiments the ${ }^{64} \mathrm{Cu}$ and the increased stable $\mathrm{Cu}$ in plasma were associated with albumin.

5. The experiments explain the effectiveness of thiomolybdates as 'decoppering' agents and provide a model for some of the systemic effects seen in ruminants exposed to increased dietary Mo. The experiments support the view that the thiomolybdates, by causing the appearance of new ligands, alter the distribution of $\mathrm{Cu}$ in tissues and cause an overall depletion.

The importance of dietary molybdenum as a causative factor in the complex secondary copper deficiency syndromes of ruminants is well-known. The role of thiomolybdates as mediators of Mo toxicity has been reviewed recently (Mason, 1986). In the review it was suggested that the increased levels of trichloroacetic acid (TCA)-insoluble or albuminbound $\mathrm{Cu}$ in plasma, which are such a characteristic feature in sheep subjected to dietary Mo supplementation (Smith \& Wright, 1975; Lamand et al. 1980) or to direct thiomolybdate infusion (Mason et al. 1982 b; Hynes et al. 1984), could be derived from $\mathrm{Cu}$ of systemic origin rather than from an accumulation of absorbed dietary $\mathrm{Cu}$ whose uptake by liver had been inhibited. The same type of reaction is evident in cattle, thus the initial response to dietary Mo supplementation was an increase in the plasma $\mathrm{Cu}$ levels (Wang et al. 1986); the increase was less evident as the hepatic $\mathrm{Cu}$ reserves declined. In cattle plasma $\mathrm{Cu}$ associated with albumin can also be increased by direct intravenous infusion of trithiomolybdate (12-75 mg Mo over $24 \mathrm{~h}$ ) (Mason et al. 1986). However, the infusion of pharmacological amounts of thiomolybdates (>100 mg Mo) over $2 \mathrm{~h}$ (Lannon \& Mason, 1986) also raised $\mathrm{Cu}$ levels and since dietary $\mathrm{Cu}$ availability is generally rather low, about $5 \%$, it was felt unlikely that the increases recorded over this time-interval could be attributed to an accumulation of absorbed dietary $\mathrm{Cu}$. Furthermore, the increase in albumin-bound $\mathrm{Cu}$ did not appear to be a consequence of caeruloplasmin breakdown since its appearance was not accompanied by a loss of caeruloplasmin- $\mathrm{Cu}$ or a depression of ferroxidase (caeruloplasmin diamine oxidase, EC 1.16.3.1) activity (Lannon \& Mason, 1986).

Studies carried out in vivo and in vitro have provided some indication of the mechanism by which thiomolybdates may perturb systemic $\mathrm{Cu}$ distribution and metabolism. The compounds, arising from the transformation of molybdates in the rumens of sheep (Mason et al. 1982a) or cattle (Hynes et al. 1984), bind reversibly to albumin. As such they appear 
to be relatively stable and protected against hydrolysis (Hynes et al. 1984; Mason, 1986). In vitro, trithiomolybdate binds to bovine serum albumin (BSA) at a single site (Woods \& Mason, 1987); the site appears to be quite distinct from the $\mathrm{N}$-terminal-binding site for $\mathrm{Cu}^{\mathrm{II}}$ (and $\mathrm{Ni}^{\mathrm{II}}$ ) since canine serum albumin (CSA), which effectively lacks the N-terminal$\mathrm{Cu}^{\mathrm{II}}$-binding site, also participates in the same type of interaction (Woods \& Mason, 1987). The affinity of the thiomolybdate-binding site, but not the number of binding sites, was increased by the presence of $\mathrm{Cu}$, and the thiomolybdate- $\mathrm{Cu}$-protein interaction was reversible. These indications of a specific three-way reversible interaction are compatible with observations in vivo in cattle (Hynes et al. 1985) in which $\mathrm{Cu}$ injection delayed the movement of ${ }^{35} \mathrm{~S}$ - and ${ }^{99} \mathrm{Mo}$-labelled trithiomolybdates into extravascular space. Thus, from present evidence, it appears that trithiomolybdate can bind to at least one protein, that is albumin, and that the bound compound can act as a new $\mathrm{Cu}$ ligand, at a site which is quite distinct from the $\mathrm{N}$-terminal site generally held to be the physiological $\mathrm{Cu}$ ligand in plasma.

$\left[{ }^{35}\right.$ S]trithiomolybdate was also shown to appear and indeed to accumulate in liver in cattle after intravenous injection of tracer amounts (Wang et al. 1988), and radioactivity was present in all the subcellular fractions examined. In the liver cytosol at least two characteristic binding proteins, as yet unidentified, were present and the binding, as in plasma, was reversible. Thiomolybdates also alter the distribution of liver $\mathrm{Cu}$ (Kelleher \& Ivan, 1985; Wang et al. 1988). All these results suggest that the presence of thiomolybdates in tissues perturbs $\mathrm{Cu}$ metabolism by creating new $\mathrm{Cu}$ ligands on proteins; this alters the equilibria between the different $\mathrm{Cu}$ compartments and changes the distribution patterns (Gawthorne, 1985; Mason, 1986; Woods \& Mason, 1987).

The experiments reported here were designed to examine the effects of trithiomolybdate, administered directly to sheep, on systemic $\mathrm{Cu}$ metabolism and to ascertain whether any perturbation, indicated by the appearance of increased albumin-bound $\mathrm{Cu}$, was accompanied by increased $\mathrm{Cu}$ excretion and overall depletion. The animals employed were placed on a low- $\mathrm{Cu}$ diet to minimize any contribution of dietary $\mathrm{Cu}$ to the plasma interactions and to facilitate the detection of increased excretion of systemic $\mathrm{Cu}$ in urine or faeces. The effect of trithiomolybdate on the animal's own (stable) $\mathrm{Cu}$ metabolism and on the fate of ${ }^{64} \mathrm{Cu}$ tracer was followed. Trithiomolybdate rather than tetrathiomolybdate was used since the latter, unlike trithiomolybdate (Mason et al. 1982a; Hynes et al. 1985), has not been detected in ruminant plasma in vivo.

\section{MATERIALS AND METHODS}

\section{Animals}

The sheep used were drawn from a pool of six Texel wethers, weighing between 60 and $71 \mathrm{~kg}$ live weight. Before the experiments the animals were transferred progressively to a low- $\mathrm{Cu}$ diet, so that for 2 weeks before and during the experiments they were maintained entirely on a special concentrate-hay $(600: 400, \mathrm{w} / \mathrm{w})$ regimen. This supplied $2.95 \mathrm{mg}$ $\mathrm{Cu} / \mathrm{d}$ per animal. Before the change to the low-Cu diet the animals' normal diet was supplemented with $10 \mathrm{mg} \mathrm{Cu}$ (as copper sulphate)/d for $10 \mathrm{~d}$ to try to ensure that the animals' $\mathrm{Cu}$ reserves were adequate. For the experiments the animals were retained in metabolism cages and urine and faeces collected to monitor both stable $\mathrm{Cu}$ and ${ }^{64} \mathrm{Cu}$ excretion.

The concentrate component of the diet (pelleted) contained $(\mathrm{g} / \mathrm{kg}): 280$ milled straw, 600 maize, 60 milk powder, 40 caramel, $20 \mathrm{Cu}$-free mineral mix. The hay was trace-elementpoor material collected in the Auvergne region; the diet was palatable and readily consumed. 


\section{Blood samples and plasma stable $\mathrm{Cu}$ and ${ }^{64} \mathrm{Cu}$}

Blood samples were obtained from the jugular vein into heparinized vacutainers. After centrifugation, the level of $\mathrm{Cu}$ in the plasma samples was assessed by dilution in distilled water containing butanol $(60 \mathrm{ml} / 1)$ and direct estimation by atomic absorption spectrophotometry. TCA-soluble and TCA-insoluble ${ }^{64} \mathrm{Cu}$ were estimated by the techniques described for ${ }^{99} \mathrm{Mo}$ by Mason et al. (1978). The plasma samples destined for Sephadex G100 gel filtration were used immediately after centrifugation; those for $\mathrm{Cu}$ determinations were stored at $-20^{\circ}$. The total radioactivity present in plasma was estimated by assuming a blood volume of $7 \%$ body-weight and a plasma volume of $65 \%$ blood volume.

\section{Stable $\mathrm{Cu}$ and ${ }^{64} \mathrm{Cu}$ excretion}

Control and experimental sheep were placed in the metabolism cages for some time before the administration of thiomolybdates and ${ }^{64} \mathrm{Cu}$ (experimental animals) or ${ }^{64} \mathrm{Cu}$ alone (controls); details of the two experimental series are recorded in the Results section. Urine and faeces were collected separately; faeces by means of sacks held in place with a harness. Urine volume and faecal weight, per $24 \mathrm{~h}$, or more frequently (see Results), were recorded and $5-\mathrm{ml}$ portions of urine taken for stable $\mathrm{Cu}$ and ${ }^{64} \mathrm{Cu}$ assessment. Faecal ${ }^{64} \mathrm{Cu}$ was estimated by counting three separately weighed samples of about $3.5 \mathrm{~g}$ taken randomly from each collection period. The narrow range of values obtained (and the averages) are shown in the Results section. Faecal stable $\mathrm{Cu}$ excretion was estimated by drying the entire amount excreted during each $24 \mathrm{~h}$ collection period at $70^{\circ}$, after at least $120 \mathrm{~h}$ storage (i.e. after ten times the ${ }^{64} \mathrm{Cu}$ half-life had elapsed), then milling, followed by estimation of the $\mathrm{Cu}$ content of sub-samples after wet-ashing.

\section{Trithiomolybdate preparation and administration}

Trithiomolybdate was prepared and purified by Sephadex G-25 chromatography by the techniques described by Kelleher \& Mason (1986) $24 \mathrm{~h}$ before use and stored in phosphate buffer at $\mathrm{pH} 7.6$ and $4^{\circ}$. Before injection, the portions, diluted in saline $(9 \mathrm{~g}$ sodium chloride/l), were checked spectrally to verify that deterioration had not occurred. Administration to the experimental animals of $30 \mathrm{mg} \mathrm{Mo} / \mathrm{d}$ as trithiomolybdate was by intravenous injection into a jugular vein over 1-2 min; six injections of $5 \mathrm{mg}$ Mo were spread throughout the day and were generally given at $09.00,10.00,11.00,20.00,21.00$ and 22.00 hours. When $10 \mathrm{mg} \mathrm{Mo} / \mathrm{d}$ was administered this was given in two doses of $5 \mathrm{mg} \mathrm{Mo}$ at 09.00 and 21.00 hours.

\section{RESULTS \\ Expt 1}

Four sheep were involved in Expt 1. The two control animals, nos. 3 and 4, were held in the metabolism cages for $7 \mathrm{~d}$ before and $4 \mathrm{~d}$ after the intravenous administration, via the jugular vein, of ${ }^{64} \mathrm{Cu}\left(1.5 \mathrm{mCi}{ }^{64} \mathrm{Cu}, 0.35 \mathrm{mg} \mathrm{Cu}\right.$, as the chloride; Amersham International plc, Amersham, Bucks) in physiological saline $(5 \mathrm{ml})$. The two experimental animals, nos. 1 and 2, were put into the cages and given ${ }^{64} \mathrm{Cu}$ at the same time but were also injected with $30 \mathrm{mg} \mathrm{Mo}$, as trithiomolybdate/animal per $\mathrm{d}$ for $3 \mathrm{~d}$ before and $1 \mathrm{~d}$ after the administration of the ${ }^{64} \mathrm{Cu}$. The ${ }^{64} \mathrm{Cu}$ was administered, on day 4 , at 11.15 hours after the three morning injections of trithiomolybdate. The experimental animals were retained in the cages for $3 \mathrm{~d}$ longer than the controls.

${ }^{64} \mathrm{Cu}$ metabolism and excretion. The ${ }^{64} \mathrm{Cu}$ injected disappeared rapidly from the plasma of the control animals (Fig. 1) so that after $3 \mathrm{~h}$ less than $5 \%$ of the dose injected could be accounted for in plasma, moreover the radioactivity was virtually all TCA-soluble. By 


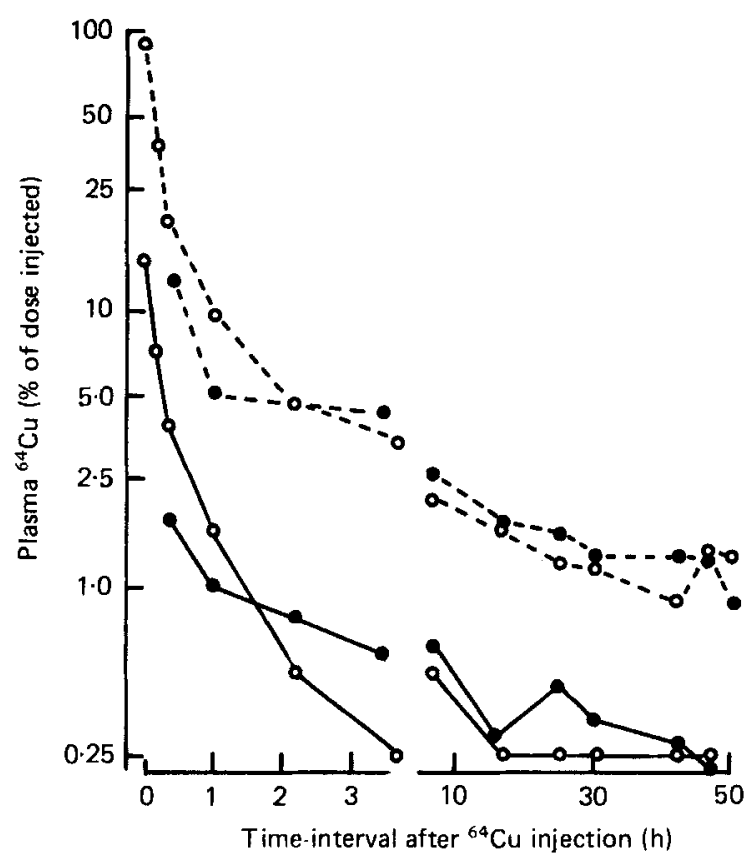

Fig. 1. Expt 1. The levels of ${ }^{64} \mathrm{Cu}$ in plasma after intravenous injections of $1.5 \mathrm{mCi}{ }^{64} \mathrm{Cu}(0.35 \mathrm{mg} \mathrm{Cu}) /$ animal into two control sheep maintained on a low-Cu diet $(2.95 \mathrm{mg} / \mathrm{d})$. (O), Animal no. 3; (O), animal no. $4 ;(-)$, trichloroacetic acid (TCA)-insoluble ${ }^{64} \mathrm{Cu} ;(--)$, TCA-soluble ${ }^{64} \mathrm{Cu}$. For details of dietary regimen, see p. 290.

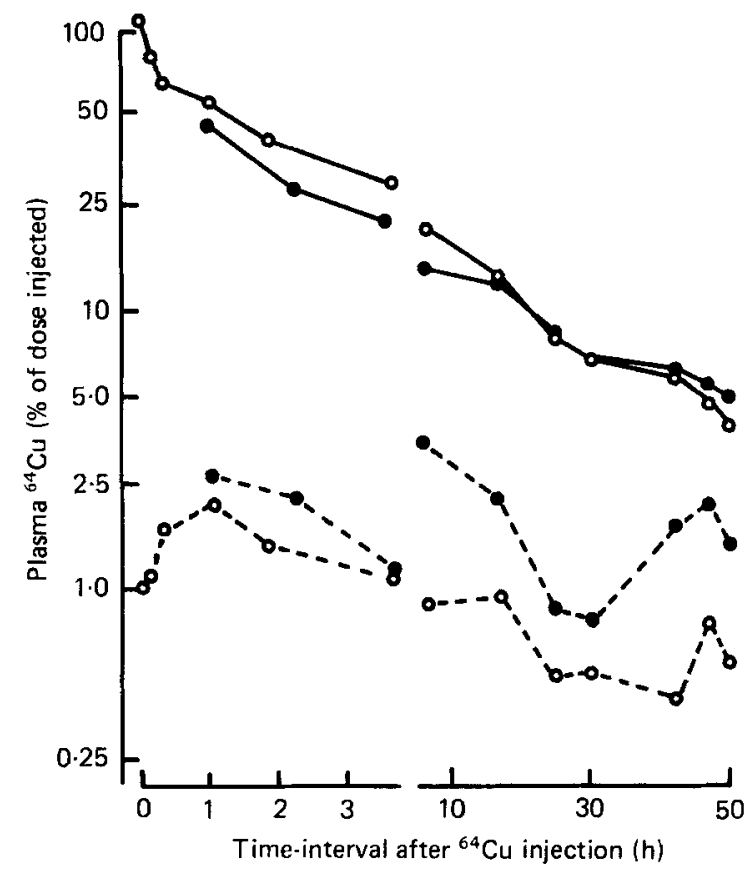

Fig. 2. Expt 1. The levels of ${ }^{64} \mathrm{Cu}$ in plasma after intravenous injection of $1.5 \mathrm{mCi}(0.35 \mathrm{mg} \mathrm{Cu}) / \mathrm{animal}$ into two experimental sheep each receiving $30 \mathrm{mg}$ molybdenum intravenously/d, as trithiomolybdate, for $3 \mathrm{~d}$ before the day of the ${ }^{64} \mathrm{Cu}$ injection and for $30 \mathrm{~h}$ post-injection. $(O)$, Animal no. $1 ;(O)$, animal no. $2 ;(+)$, trichloroacetic acid (TCA)-insoluble ${ }^{64} \mathrm{Cu} ;(--)$, TCA-soluble ${ }^{64} \mathrm{Cu}$. The animals were maintained on a low-Cu diet $(2 \cdot 95 \mathrm{mg} / \mathrm{d})$. For details of dietary regimen, see p. 290. 


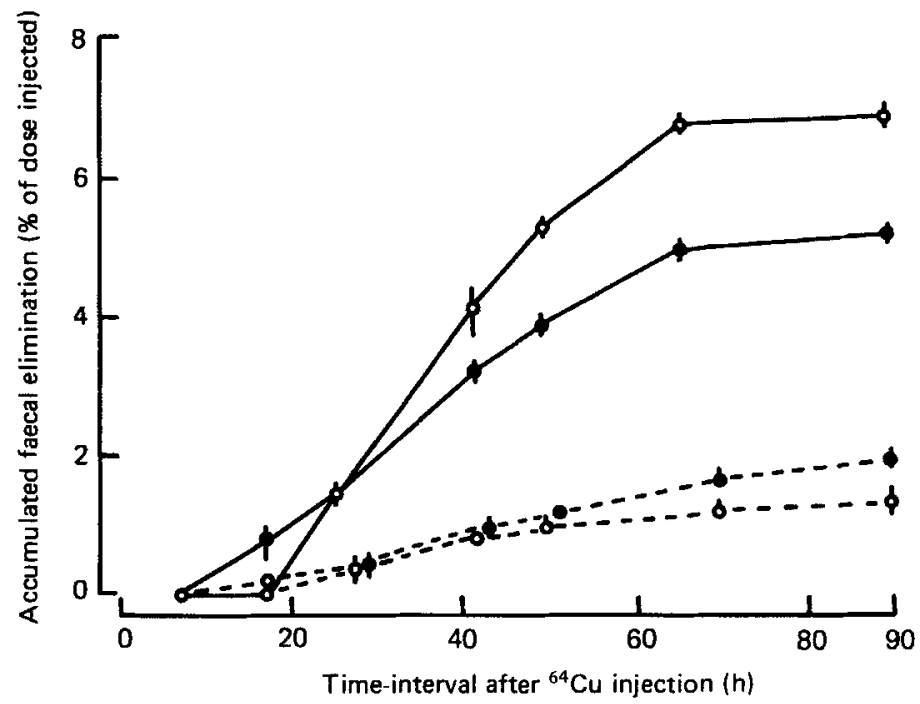

Fig. 3. Expt 1. Faecal elimination of ${ }^{64} \mathrm{Cu}$ after intraveneous injection of $1.5 \mathrm{mCi}{ }^{64} \mathrm{Cu}(0.35 \mathrm{mg} \mathrm{Cu}) /$ animal into four sheep maintained on a low-Cu diet $(2.95 \mathrm{mg} / \mathrm{d}) .(\mathrm{O}-\mathrm{O},-\cdots)$, Animal nos. 1 and 2; each injected with $30 \mathrm{mg}$ molybdenum/ $\mathrm{d}$ as trithiomolybdate, for $3 \mathrm{~d}$ before and $1 \mathrm{~d}$ after the ${ }^{64} \mathrm{Cu}$ injection. ( $\mathrm{O}-\mathrm{O}, \mathrm{O}^{--}$), Control animals nos. 3 and 4 . For details of dietary regimen, see p. 290. Points are means with their ranges represented by vertical bars.

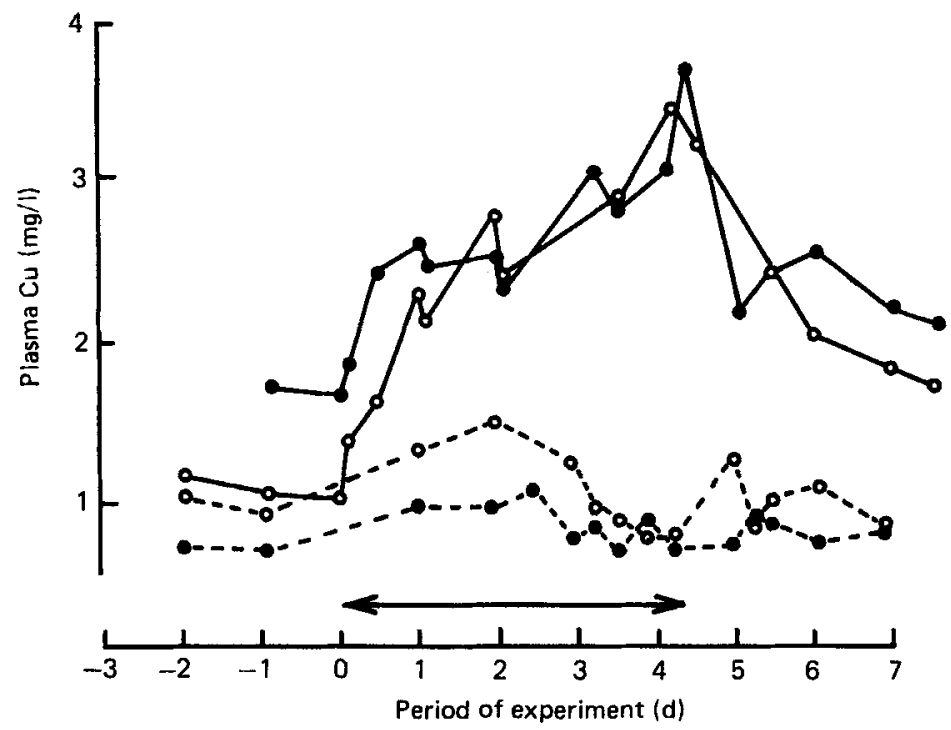

Fig. 4. Expt 1. The levels of copper in plasma, in control animal nos. 3 and 4 (O--O, --0$)$; and in animal nos. 1 and 2 each injected with $30 \mathrm{mg}$ molybdenum/d as trithiomolybdate $(\mathrm{O}-\mathrm{O}$, ) over days $1-5 . \leftrightarrow$, Trithiomolybdate administration.

contrast the disappearance of ${ }^{64} \mathrm{Cu}$ from the plasma of the experimental animals receiving trithiomolybdate was greatly slowed (Fig. 2) so that after $3 \mathrm{~h} 25 \%$ or more of the radioactivity injected was still present. In addition the radioactivity was virtually all TCAinsoluble (Fig. 2). Faecal excretion of radioactivity was higher in the experimental animals (Fig. 3). Thus in animal nos. 1 and 2 injected with trithiomolybdate, 6.75 and $5 \%$ of the ${ }^{64} \mathrm{Cu}$ administered was recovered in the faeces in the $90 \mathrm{~h}$ following intravenous injection. Over the same period less than $2 \%$ was recovered from the controls (Fig. 3). Smaller 


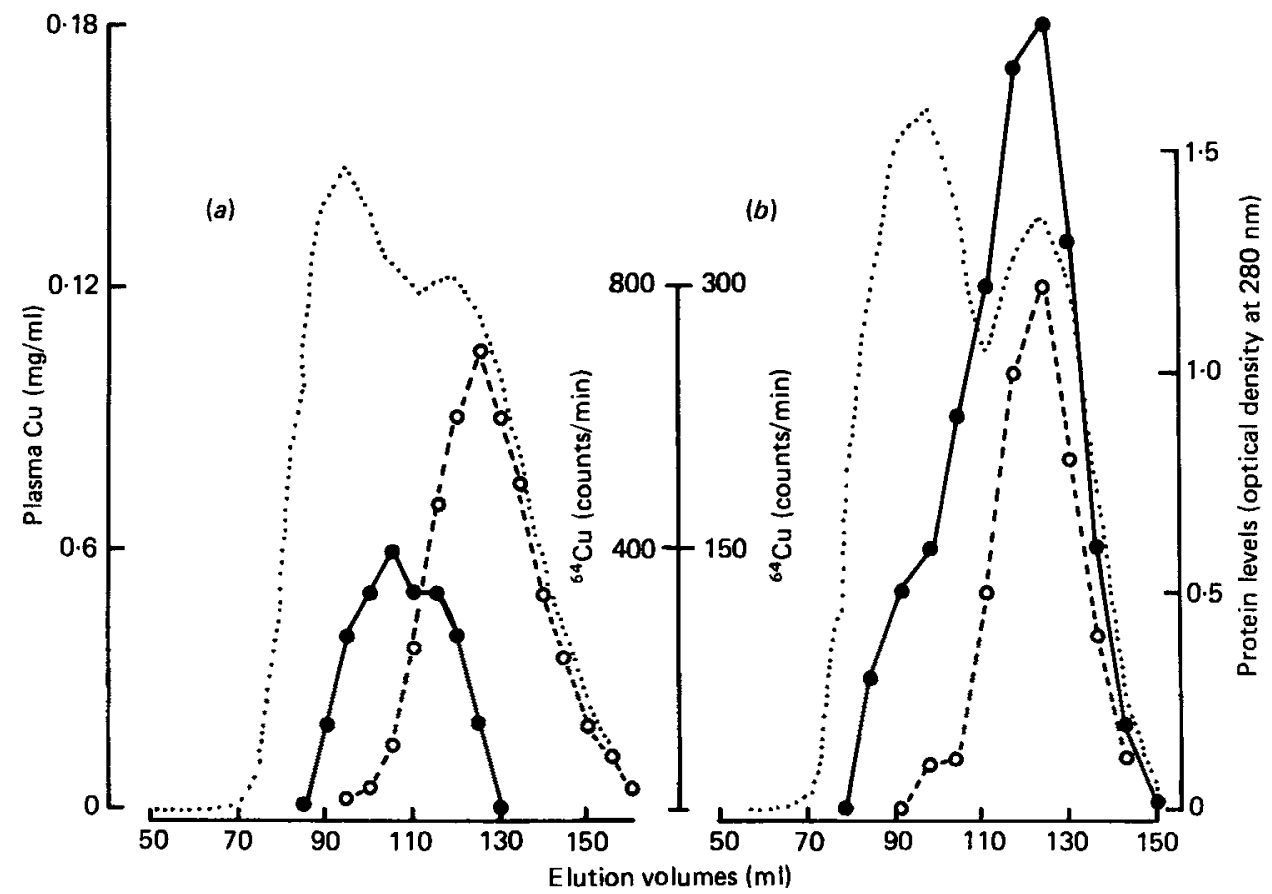

Fig. 5. Sephadex G-100 gel-filtration of plasma $(2 \mathrm{ml})$ obtained $(a)$ from control animal no. 3, 1 min after the intravenous injection of ${ }^{64} \mathrm{Cu},(b)$ from experimental animal no. 1 injected with $30 \mathrm{mg}$ molybdenum/ $\mathrm{d}$, as trithiomolybdate, for $3 \mathrm{~d}$ before the ${ }^{64} \mathrm{Cu}$ administration; the plasma sample was obtained $1 \mathrm{~h}$ after the ${ }^{64} \mathrm{Cu}$ injection. Both sheep were maintained on a low-Cu diet $(2.95 \mathrm{mg} / \mathrm{d}) .(\ldots)$, Protein profile; $\left(\mathrm{O}-\mathrm{Cu}\right.$ in eluate; $\left(\mathrm{O}^{-}-\mathrm{O}\right)$, radioactivity $\left({ }^{64} \mathrm{Cu}\right)$. Column size $500 \times 25 \mathrm{~mm}$. Elution: Tris-acetate buffer ( $50 \mathrm{~mm})$ at $\mathrm{pH} 7.4$ and $4^{\circ}$. For details of dietary regimen, see p. 290.

Table 1. Expt 1. Daily faecal and urinary excretion of stable copper ( $m g$ ) after trithiomolybdate injection

(Sheep nos. 1 and 2, the experimental animals, were injected with $30 \mathrm{mg}$ molybdenum (as trithiomolybdate)/d from day 1 to day 5 . All animals received $2.95 \mathrm{mg} \mathrm{Cu} / \mathrm{d}$ in the diet)

\begin{tabular}{|c|c|c|c|c|c|c|c|c|}
\hline \multirow{3}{*}{$\begin{array}{c}\text { Sheep no.... } \\
\text { Day }\end{array}$} & \multicolumn{4}{|c|}{ Experimental animals } & \multicolumn{4}{|c|}{ Controls } \\
\hline & \multicolumn{2}{|c|}{1} & \multicolumn{2}{|c|}{2} & \multicolumn{2}{|c|}{3} & \multicolumn{2}{|c|}{4} \\
\hline & Faeces & Urine & Faeces & Urine & Faeces & Urine & Faeces & Urine \\
\hline-5 & $2 \cdot 78$ & 0.42 & $2 \cdot 94$ & 0.30 & $3 \cdot 51$ & 0.48 & & \\
\hline-4 & 3.45 & 0.25 & $2 \cdot 84$ & $0 \cdot 24$ & $3 \cdot 57$ & $0 \cdot 24$ & & \\
\hline-3 & 3.26 & $0 \cdot 19$ & $2 \cdot 92$ & $0 \cdot 30$ & $3 \cdot 41$ & $0 \cdot 28$ & & \\
\hline-2 & 3.65 & 0.13 & $3 \cdot 26$ & 0.17 & $2 \cdot 64$ & 0.12 & \multicolumn{2}{|c|}{ Not available } \\
\hline$-\overline{1}$ & $3 \cdot 10$ & $0 \cdot 11$ & 3.039 & 0.09 & $2 \cdot 83$ & 0.13 & & \\
\hline 1 & $4 \cdot 20$ & $0 \cdot 10$ & 3.037 & $0 \cdot 10$ & $2 \cdot 54$ & 0.08 & & \\
\hline 2 & 5.92 & 0.10 & 4.89 & 0.09 & 2.69 & 0.07 & 3.01 & 0.69 \\
\hline 3 & $5 \cdot 20$ & $0 \cdot 15^{*}$ & 5.98 & $0 \cdot 13^{*}$ & $2 \cdot 82$ & $0 \cdot 11 *$ & $3 \cdot 03$ & $0.37^{*}$ \\
\hline 4 & 7.06 & $0.15 *$ & $4 \cdot 37$ & $0.13^{*}$ & 2.98 & $0 \cdot 11^{*}$ & 3.48 & $0.37^{*}$ \\
\hline 5 & 6.24 & $0.15^{*}$ & 4.45 & $0.13^{*}$ & 2.79 & $0.11^{*}$ & $3 \cdot 15$ & $0.37^{*}$ \\
\hline 6 & 4.07 & 0.24 & $3 \cdot 28$ & $0 \cdot 14$ & 2.99 & 0.15 & 2.93 & 0.21 \\
\hline 7 & 3.23 & 0.45 & $3 \cdot 11$ & 0.33 & \multicolumn{2}{|c|}{-} & \multicolumn{2}{|c|}{ - } \\
\hline 8 & 2.28 & 0.25 & 3.05 & 0.12 & \multicolumn{2}{|c|}{-} & \multicolumn{2}{|c|}{-} \\
\hline 9 & $2 \cdot 19$ & 0.17 & 2.81 & 0.14 & \multicolumn{2}{|c|}{ - } & \multicolumn{2}{|c|}{-} \\
\hline
\end{tabular}

* During days $3-5$ after the injection of ${ }^{64} \mathrm{Cu}$, the urine was pooled and stored. The $\mathrm{Cu}$ analyses were carried out on the pooled samples; urine values for days 3,4 , and 5 are thus average values. 


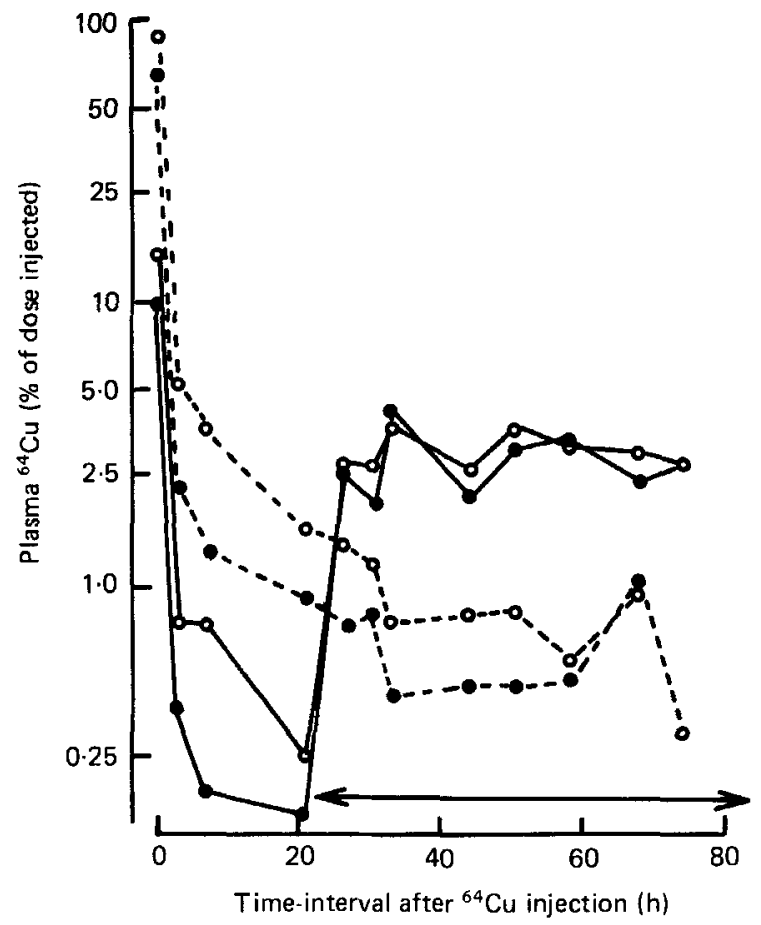

Fig. 6. Expt 2. The levels of ${ }^{64} \mathrm{Cu}$ in plasma after intravenous injection of $2 \mathrm{mCi}{ }^{64} \mathrm{Cu}(0 \cdot 1 \mathrm{mg} \mathrm{Cu}) / \mathrm{animal}$ into two sheep. At $22 \mathrm{~h}$ after the ${ }^{64} \mathrm{Cu}$ injection the animals received $10 \mathrm{mg}$ molybdenum/sheep per $\mathrm{d}$ as trithiomolybdate by intravenous injection for $3 \mathrm{~d}$. (O), Animal no. $5 ;(0)$, animal no. $6 ;(\longrightarrow)$, trichloroacetic acid (TCA)-insoluble ${ }^{64} \mathrm{Cu} ;(--)$, TCA-soluble ${ }^{64} \mathrm{Cu} . \leftrightarrow$, Trithiomolybdate administration.

quantities of radioactivity appeared in urine, thus three sheep, nos. 1, 2 and 3 excreted less than $1 \%$ over the $90 \mathrm{~h}$ collection period following ${ }^{64} \mathrm{Cu}$ injection; one of the controls, animal no. 4 , excreted $1.7 \%$ but this was probably associated with the high urine output of this animal ( $9 \cdot 71$ litres compared with $2 \cdot 5-6 \cdot 41$ litres for the others over the period) than to any real differences in renal $\mathrm{Cu}$ metabolism.

Stable $\mathrm{Cu}$ metabolism and excretion. Plasma $\mathrm{Cu}$ levels in the experimental animals were increased by the trithiomolybdate injections; the changes are illustrated in Fig. 4. The increases were not accompanied by corresponding changes in ferroxidase activity (results not shown). The maximum increases in $\mathrm{Cu}$ concentrations over the prethiomolybdate levels, that is an addition of about 2.4 and $2 \mathrm{mg} \mathrm{Cu} / 1$ plasma for animal nos. 1 and 2 respectively, corresponds to about 7.5 and $6.5 \mathrm{mg} \mathrm{Cu}$ /animal from the assumption of a blood volume of $7 \%$ body-weight and a plasma volume of $65 \%$ blood volume. Total dietary $\mathrm{Cu}$ intake over the same period would have been $11.8 \mathrm{mg} \mathrm{Cu} /$ animal.

Sephadex G-100 gel-filtration showed that the extra plasma Cu was associated with the albumin fraction. The two sample elution profiles shown in Fig. 5 of plasma from control animal no. 3, $1 \mathrm{~min}$ after ${ }^{64} \mathrm{Cu}$ injection (Fig. 5(a)) and from experimental sheep no. 1, $1 \mathrm{~h}$ after ${ }^{64} \mathrm{Cu}$ and after $3 \mathrm{~d}$ of thiomolybdate injections (Fig. $5(b)$ ), show that in both cases the radioactivity was also associated with albumin. It is clear from the elution profile of the control animal in Fig. 5(a) that the caeruloplasmin-Cu peak eluting at around $105 \mathrm{ml}$ is quite distinct from the ${ }^{64} \mathrm{Cu}$ associated with albumin, whereas the large increase in stable $\mathrm{Cu}$ in the experimental animal (Fig. 5(b)) is virtually coincident with the ${ }^{64} \mathrm{Cu}$ peak eluting at about $125 \mathrm{ml}$. Presumably the slight early shoulder represents the caeruloplasmin-Cu peak now masked by the $\mathrm{Cu}$ associated with albumin. 


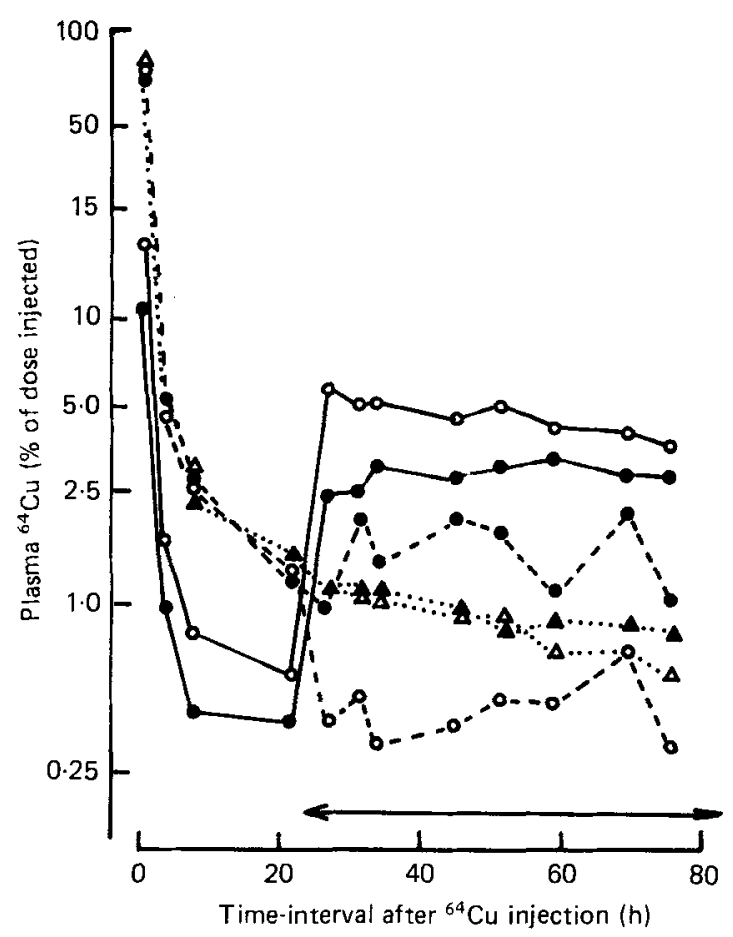

Fig. 7. Expt 2. The levels of ${ }^{64} \mathrm{Cu}$ in plasma after intravenous injection of $2 \mathrm{mCi}^{64} \mathrm{Cu}(0 \cdot 1 \mathrm{mg} \mathrm{Cu}) / \mathrm{animal}$ into four sheep. $(\triangle \ldots \triangle, \Delta \ldots \Delta)$, Control animal nos. 2 and 4 , trichloroacetic acid (TCA)-soluble ${ }^{64} \mathrm{Cu} ;(\mathrm{O}, \mathrm{O})$, experimental animal nos. 1 and 3 , received in addition $22 \mathrm{~h}$ after the ${ }^{64} \mathrm{Cu}, 30 \mathrm{mg}$ molybdenum/sheep per $\mathrm{d}$ as trithiomolybdate by intravenous injection for $3 \mathrm{~d}$. ( -.), TCA-insoluble ${ }^{64} \mathrm{Cu}$; (- - ), TCA-soluble ${ }^{64} \mathrm{Cu} \leftrightarrow$, Trithiomolybdate administration.

The appearance of albumin-bound $\mathrm{Cu}$ in the experimental animals was accompanied by increased $\mathrm{Cu}$ excretion. Table 1 shows that while the control animals, nos. 3 and 4, were not far from $\mathrm{Cu}$ balance throughout the experiment, as were the experimental sheep before, and after the cessation of the trithiomolybdate administration, the daily faecal output of $\mathrm{Cu}$ was increased by some $2-4 \mathrm{mg} / \mathrm{d}$ as a result of the trithiomolybdate injections. Rough calculations from the values in Table 1 show that animal nos. 1 and 2 lost about 15 and $8 \mathrm{mg} \mathrm{Cu}$ respectively by this route as a result of the trithiomolybdate. By contrast urinary $\mathrm{Cu}$ excretion was unaffected (Table 1).

\section{Expt 2}

This experiment was designed to examine the effect of trithiomolybdate on the fate of ${ }^{64} \mathrm{Cu}$ already in the extravascular tissues rather than ${ }^{64} \mathrm{Cu}$ labelling the plasma pool. The experiment was carried out 2 weeks after the end of Expt 1 and all six animals were used. Animal nos. 2 and 4, sham-injected with saline rather than trithiomolybdate, served as control animals; they received ${ }^{64} \mathrm{Cu}(2 \mathrm{mCi}, 0 \cdot 1 \mathrm{mg} \mathrm{Cu})$ by intravenous injection $24 \mathrm{~h}$ after faeces (and urine) collection began. The experimental animals were, in addition, injected intravenously with either 30 (animals nos. 1 and 3 ) or 10 (nos. 5 and 6) $\mathrm{mg}$ Mo as trithiomolybdate $/ \mathrm{d}$, starting $22 \mathrm{~h}$ after the ${ }^{64} \mathrm{Cu}$ injections and continuing for $3 \mathrm{~d}$. Only four metabolism cages were available so that animal nos. 2 and 5 remained in pens and were fitted with harnesses for faecal collection alone.

Plasma ${ }^{64} \mathrm{Cu}$ metabolism and ${ }^{64} \mathrm{Cu}$ excretion. In all the animals the ${ }^{64} \mathrm{Cu}$ disappeared 


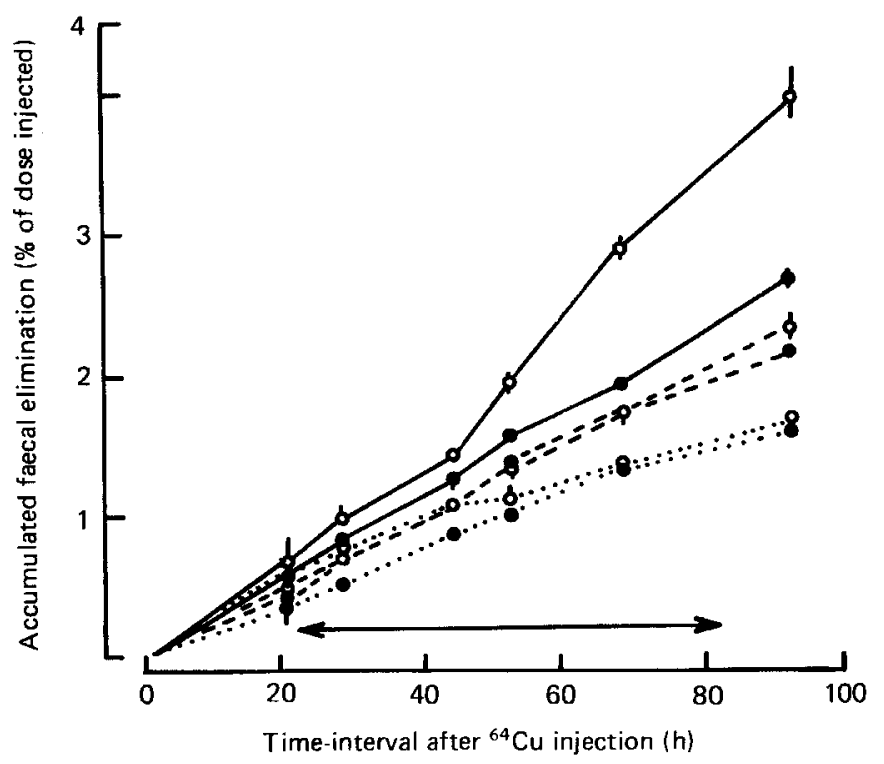

Fig. 8. Expt 2. Faecal elimination of ${ }^{64} \mathrm{Cu}$ after intravenous injection of $2 \mathrm{mCi}{ }^{64} \mathrm{Cu}(0 \cdot 1 \mathrm{mg} \mathrm{Cu}) /$ animal into six sheep maintained on a low-Cu diet $(2.95 \mathrm{mg} / \mathrm{d}) .(\mathrm{O}-\mathrm{O}, \mathrm{O}-\mathrm{O})$, Animal nos. 1 and 3 each received in addition $30 \mathrm{mg}$ molybdenum/d as trithiomolybdate by intravenous injection; $\left(\mathrm{O}^{-}-\mathrm{O}\right.$, --O) animal nos. 5 and 6 received $10 \mathrm{mg} \mathrm{Mo/sheep} \mathrm{per} \mathrm{d} ;(\mathrm{O} \ldots \mathrm{O}, \mathrm{O} \ldots \mathrm{O})$ animal nos. 2 and 4, sham-injected controls. Point are means with their ranges represented by vertical bars, for three random samples taken from the pooled faecal output for each sheep. For details of dietary regimen, see p. $290 . \longleftrightarrow$, Trithiomolybdate administration.

rapidly from plasma so that just before the trithiomolybdate injections only about $1 \%$ remained in plasma and this was overwhelmingly TCA-soluble. The injection of trithiomolybdate caused an immediate reappearance of ${ }^{64} \mathrm{Cu}$ in plasma. Fig. 6 shows results from the animals given $10 \mathrm{mg} \mathrm{Mo} / \mathrm{d}$, i.e. nos. 5 and 6 . Levels of TCA-insoluble ${ }^{64} \mathrm{Cu}$ increased rapidly after the first injection of $5 \mathrm{mg} \mathrm{Mo}$, from $0.25 \%$ of the dose injected to $2 \cdot 5-5 \%$. By contrast the levels of TCA-soluble ${ }^{64} \mathrm{Cu}$ appeared unaffected. The levels of TCA-insoluble ${ }^{64} \mathrm{Cu}$ then showed only a slow decline. The short half-life of the isotope $(12 \mathrm{~h})$ made it impossible to follow plasma levels for a longer period than the $75 \mathrm{~h}$ illustrated. The results for the animals injected with $30 \mathrm{mg} \mathrm{Mo} / \mathrm{d}$ as trithiomolybdate (Fig. 7) were rather similar except that a higher proportion of the plasma radioactivity was TCA-soluble in sheep no. 3. In the control, sham-injected animals (Fig. 7) there was no increase in plasma radioactivity and the residual ${ }^{64} \mathrm{Cu}$ was overwhelmingly TCA-soluble throughout the experiment.

Fig. 8 shows that there were differences in faecal ${ }^{64} \mathrm{Cu}$ excretion over the $92 \mathrm{~h}$ following the ${ }^{64} \mathrm{Cu}$ injection. Thus while the two control animals, nos. 2 and 4 , lost 1.75 and $1.6 \%$ respectively, the experimental animals lost $2 \cdot 3$ and $2 \cdot 1$ (nos. 5 and 6 ) and 4 and $2.6 \%$ (nos. 1 and 3 ). The differences would probably have been more pronounced if enough radioactivity had remained to enable the counting of faecal samples to continue for longer. As in Expt 1 urine excretion was low and unaffected by the trithiomolybdate injections (Table 2), thus in the $3 \mathrm{~d}$ following the ${ }^{64} \mathrm{Cu}$ injection the animals for which urine collection was possible, i.e. nos. $1,3,4$ and 6 excreted $1.25,0.59,1.78$ and $1.8 \%$ respectively. However, most of this, that is $1.06,0.40,1.03$ and $1.5 \%$, was excreted in the $22 \mathrm{~h}$ preceding the administration of trithiomolybdate. As in Expt 1 the amount of ${ }^{64} \mathrm{Cu}$ excreted by this route 
Table 2. Expt 2. Daily faecal and urinary excretion of stable copper ( $m g$ ) after trithiomolybdate injection

(Animal nos. 1 and 3 were injected with $30 \mathrm{mg}$ molybdenum/d for $3 \mathrm{~d}$ (days 1-3); animal nos. 5 and 6 with $10 \mathrm{mg} \mathrm{Mo} / \mathrm{d}$ for $3 \mathrm{~d}$ (days 1-3) as trithiomolybdate; animals nos. 2 and 4 were sham-injected controls)

\begin{tabular}{|c|c|c|c|c|c|c|c|c|c|c|}
\hline \multirow{3}{*}{$\begin{array}{c}\text { Sheep no.... } \\
\text { Day }\end{array}$} & \multicolumn{7}{|c|}{ Experimental sheep } & \multicolumn{3}{|c|}{ Controls } \\
\hline & \multicolumn{2}{|c|}{1} & \multicolumn{2}{|c|}{3} & \multirow{2}{*}{$\begin{array}{c}5 \\
\text { Faeces }\end{array}$} & \multicolumn{2}{|c|}{6} & \multirow{2}{*}{$\begin{array}{c}2 \\
\text { Faeces }\end{array}$} & \multicolumn{2}{|c|}{4} \\
\hline & Faeces & Urine & Faeces & Urine & & Faeces & Urine & & Faeces & Urine \\
\hline-3 & $2 \cdot 49$ & $0 \cdot 25$ & $2 \cdot 91$ & $0 \cdot 10$ & $3 \cdot 28$ & $2 \cdot 66$ & $0 \cdot 32$ & 1.97 & $2 \cdot 10$ & $0 \cdot 54$ \\
\hline-2 & $2 \cdot 73$ & $0 \cdot 23$ & $3 \cdot 15$ & 0.09 & $2 \cdot 60$ & $2 \cdot 97$ & 0.03 & 3.05 & 2.90 & $0-49$ \\
\hline-1 & $2 \cdot 69$ & $0 \cdot 23$ & $2 \cdot 35$ & 0.08 & $2 \cdot 41$ & $2 \cdot 84$ & $0-36$ & $2 \cdot 49$ & $2 \cdot 60$ & $0 \cdot 39$ \\
\hline I & $2 \cdot 53$ & $0 \cdot 16$ & 2.43 & $0 \cdot 11$ & $2 \cdot 77$ & $2 \cdot 50$ & 0.26 & $2 \cdot 61$ & $2 \cdot 33$ & $0 \cdot 30$ \\
\hline 2 & 3.69 & $0 \cdot 13$ & $2 \cdot 46$ & 0.07 & $2 \cdot 69$ & 3.07 & $0 \cdot 27$ & $2 \cdot 46$ & $2 \cdot 31$ & $0 \cdot 30$ \\
\hline 3 & $4 \cdot 10$ & 0.12 & 2.39 & 0.07 & 2.96 & $3 \cdot 36$ & 0.26 & $2 \cdot 32$ & $2 \cdot 43$ & $0-35$ \\
\hline 4 & 5.52 & 0.16 & $3 \cdot 29$ & 0.05 & $2 \cdot 52$ & $3 \cdot 28$ & 0.22 & 2.85 & 3.09 & 0.26 \\
\hline 5 & 3.08 & - & $2 \cdot 37$ & - & $3 \cdot 18$ & 2.54 & 0.27 & 3.02 & 2.96 & - \\
\hline 6 & $2 \cdot 62$ & 0.24 & $2 \cdot 86$ & 0.05 & 3.03 & 3.01 & $0 \cdot 22$ & 2.93 & $2 \cdot 43$ & 0.26 \\
\hline 7 & $2 \cdot 35$ & $0 \cdot 14$ & $2 \cdot 39$ & 0.05 & 3.09 & $2 \cdot 71$ & 0.28 & 2.99 & $2 \cdot 41$ & 0.25 \\
\hline 8 & $2 \cdot 19$ & 0.09 & 2.45 & 0.08 & $2 \cdot 90$ & 3.06 & 0.26 & 293 & $2 \cdot 94$ & 0.23 \\
\hline
\end{tabular}

appears to be at least partially dependent on the volume of urine excreted, which was $5 \cdot 15$, $5.45,13.5$ and 9 litres over the $3 \mathrm{~d}$ and $1.5,1.3,2.9$ and 1.7 litres over the first $22 \mathrm{~h}$ for animals nos. 1, 3, 4 and 6 respectively. The low residual levels of radioactivity prevented the continuation of counting.

Plasma stable Cu levels and stable Cu excretion. As in Expt 1 the plasma Cu levels rose as the number of thiomolybdate injections increased. In the animals receiving $30 \mathrm{mg} \mathrm{Mo} /$ $\mathrm{d}$ as trithiomolybdate, i.e. nos. 1 and 3 , levels had increased by 2.14 and $0.5 \mathrm{mg} / 1$ plasma at the end of the 3rd day of injections; the plasma $\mathrm{Cu}$ of animals which received $10 \mathrm{mg} /$ d, i.e. nos. 5 and 6 , rose by 0.53 and $2 \cdot 10 \mathrm{mg} / 1$ respectively over this period. Levels in the sham-injected control sheep, nos. 2 and 4 , changed by +0.07 and $-0.09 \mathrm{mg} / 1$. Sephadex G-100 gel-filtration of plasma from the trithiomolybdate-treated animals showed that both the additional $\mathrm{Cu}$ and the radioactivity which had reappeared were associated with albumin (not shown). In the two animals showing the largest increases, i.e. animal nos. 1 and 6, the change would represent about 6.5 and $6.2 \mathrm{mg}$ extra $\mathrm{Cu}$ in the estimated total plasma. The dietary $\mathrm{Cu}$ intake over this period was $7.4 \mathrm{mg}$. The daily faecal and urinary stable $\mathrm{Cu}$ excretion is shown in Table 2. Only in animal no. 1, which excreted $3 \cdot 69,4 \cdot 10$ and 5.52 $\mathrm{mg} \mathrm{Cu}$ in the $2 \mathrm{nd}, 3 \mathrm{rd}$ and 4 th days respectively after the start of the thiomolybdate injections (compared with $2 \cdot 4-2.69 \mathrm{mg} / \mathrm{d}$ before) was there a readily discernible increase, although there may have been a very slight increase over the same period (Table 2) in animal no. 6. As in Expt 1 the urinary $\mathrm{Cu}$ excretion was low (Table 2) and unaffected by the thiomolybdate administration.

\section{DISCUSSION}

The three-way interaction of $\mathrm{Cu}$, albumin and trithiomolybdate examined in vitro by Woods \& Mason (1987) and shown to occur in vivo between $\left[{ }^{35}\right.$ S]trithiomolybdate and injected stable $\mathrm{Cu}$ in cattle (Hynes et al. 1985), was evident in these experiments. Thus the disappearance from plasma of the ${ }^{64} \mathrm{Cu}$ injected in Expt 1 was greatly delayed by the presence of trithiomolybdate. Whether the plasma interactions were responsible for the increased $\mathrm{Cu}$ excretion demonstrated or whether this resulted from effects elsewhere could not be ascertained. An increased retention in plasma as well as reduced absorption from the 
gut has been demonstrated in rats fed on tetrathiomolybdate and dosed orally with ${ }^{64} \mathrm{Cu}$ (Mills et al. 1978). While in those experiments the ${ }^{64} \mathrm{Cu}$ retained in plasma originated from the gut the present experiments show that additional plasma $\mathrm{Cu}$ can also be of tissue origin. Although the availability of the dietary $\mathrm{Cu}$ could not be determined it is generally low, about $5 \%$. This, in the present experiments, would correspond to about $0.15 \mathrm{mg} \mathrm{Cu} / \mathrm{d}$ since the sheep were maintained on a low-Cu diet which supplied $2.95 \mathrm{mg} / \mathrm{sheep}$ per d. Even if the disappearance of $\mathrm{Cu}$ from plasma were completely blocked, which was not the case since the ${ }^{64} \mathrm{Cu}$ label levels did decline, albeit slowly, the flow of $\mathrm{Cu}$ from the gut would seem insufficient to account for all the increases in plasma stable $\mathrm{Cu}$ seen in these experiments. More direct evidence of the participation of $\mathrm{Cu}$ of tissue origin in the plasma interactions was obtained in Expt 2 where the $22 \mathrm{~h}$ interval between ${ }^{64} \mathrm{Cu}$ injection and trithiomolybdate administration permitted tissue (presumably hepatic) uptake. The label readily and immediately reappeared even at the lower level of trithiomolybdate injected, that is $10 \mathrm{mg}$ $\mathrm{Mo} /$ animal per $\mathrm{d}$. The experiments confirm that trithiomolybdate exerts powerful systemic effects which alter the distribution of $\mathrm{Cu}$ in animals.

The excretion of ${ }^{64} \mathrm{Cu}$ in faeces was accelerated by trithiomolybdate irrespective of whether the ${ }^{64} \mathrm{Cu}$ was introduced into the plasma pool during trithiomolybdate treatment, as in Expt 1, or whether thiomolybdate was given after hepatic uptake had occurred, as in Expt 2. Stable $\mathrm{Cu}$ excretion also rose, thus in the first experiment where trithiomolybdate administration was continued for $5 \mathrm{~d}$ the stable $\mathrm{Cu}$ content of the faeces was more than doubled. This would represent a depletion of $3 \mathrm{mg} / \mathrm{d}$ or more. No acceleration of urinary excretion was observed and this contrasts with observations by Marcilese et al. (1970) and Gooneratne (1986), although the latter author also demonstrated increased biliary secretion. While we detected no effect of trithiomolybdate on either ${ }^{64} \mathrm{Cu}$ or stable $\mathrm{Cu}$ output in urine, there was some experimental support for Gooneratne's (1986) view that higher urine volumes contribute to increased urinary loss. While it was not possible to assess the relative contributions of either increased biliary excretion or gastrointestinal secretion of ${ }^{64} \mathrm{Cu}$ or stable $\mathrm{Cu}$ loss in the faeces, Gooneratne (Gooneratne et al. 1985; Gooneratne, 1986) showed that biliary loss increased more markedly.

Tetrathiomolybdate, which is generally more potent than trithiomolybdate (Mason, 1982), is an effective 'decoppering agent' in patients with Wilson's disease (Walshe, 1986), and will block $\mathrm{Cu}$ toxicity in sheep (Gooneratne et al. 1981) when administered directly; although it has not been demonstrated in ruminant plasma. Although caution should be exercised, it is likely to do this via a mechanism of action similar to that seen in the present experiments with trithiomolybdate, i.e. by increasing excretion (as well as by blocking absorption). While it was not shown that the stable $\mathrm{Cu}$ in plasma or faeces or the ${ }^{64} \mathrm{Cu}$ reappearing in plasma in Expt 2 originated specifically from liver, it is likely that the changes which occurred represent a perturbation of hepatic $\mathrm{Cu}$ metabolism. Recent results show that $\left[{ }^{35}\right.$ S $]$ trithiomolybdate accumulates in liver in cattle and radioactivity was present in all subcellular fractions examined (Wang et al. 1987). The distribution of $\mathrm{Cu}$ in liver is altered by trithiomolybdate administration and by increased dietary Mo (Wang et al. 1986). In sheep Kelleher \& Ivan (1985) showed that the administration of $100 \mathrm{mg}$ tetrathiomolybdate increased the $\mathrm{Cu}$ in high-molecular-weight fractions of liver cytosol. Overall the results show for the first time that trithiomolybdate, known to be present in the plasma of ruminants exposed to Mo, can have powerful systemic effects. The results may also explain the effectiveness of tetrathiomolybdate as a 'decoppering agent' and in the prevention of $\mathrm{Cu}$ toxicity. Clearly more work, particularly on the hepatic interactions, will be necessary before a molecular mechanism for the effect can be proposed. However, the results are consistent with the view (Mason, 1986) that trithiomolybdate, by causing the appearance of new ligands in tissues, alters the distribution of $\mathrm{Cu}$ between the different pools and that the perturbation can lead to an overall depletion. 
J.M. and G. M. are grateful for the financial support of the National Board for Science and Technology and for the technical assistance provided by Gerard Montal and Christian Lafarge.

\section{REFERENCES}

Gawthorne, J. M. (1985). In Ruminant Physiology, Concepts and Consequences, pp. 337--357 [S. K. Baker, J. M. Gawthorne, J. M. Mackintosh and D. B. Purser, editors]. Perth: University of Western Australia.

Gooneratne, S. R. (1986). Acta Pharmacologica et Toxiologica 59, Suppl. 7, 518-523.

Gooneratne, S. R., Christenson, D., Chaplin, R. \& Trent, A. (1985). In Trace Elements in Man and Animals, pp. 342-346 [C. F. Mills, I. Bremner and J. K. Chesters, editors]. Slough: Commonwealth Agricultural Bureaux. Gooneratne, S. R., Howell, J. McC. \& Gawthorne, J. M. (1981). British Journal of Nutrition 46, 457-480.

Hynes, M., Lamand, M., Montel, G. \& Mason, J. (1984). British Journal of Nutrition 52, 149-158.

Hynes, M., Woods, M., Poole, D., Rogers, P. \& Mason, J. (1985). Journal of Inorganic Biochemistry 24, 279-288

Kelleher, C. A. \& Ivan, M. (1985). In Trace Element Metabolism in Man and Animals, pp. 364-367 [C. F. Mills, 1. Bremner and J. K. Chesters, editors]. Slough: Commonwealth Agricultural Bureaux.

Kelleher, C. A. \& Mason, J. (1986). International Journal of Biochemistry 18, 629-635.

Lamand, M., Lab, C., Tressol, J. C. \& Mason, J. (1980). Annals of Veterinary Research 11, 141-145.

Lannon, B. \& Mason, J. (1986). Journal of Inorganic Biochemistry 26, 107-115.

Marcilese, N. A., Ammerman, C. G., Valsecchi, R. M., Dunavent, B. G. \& Davis, G. K. (1970). Journal of Nutrition 100, 1399-1406.

Mason, J. (1982). Irish Veterinary Journal 36, 164-168.

Mason, J. (1986). Toxicology 42, $99-109$.

Mason, J., Kelleher, C. A. \& Letters, J. (1982a). British Journal of Nutrition 48, 391-397.

Mason, J., I.amand, M. \& Kelleher, C. A. (1982 b). Journal of Comparative Pathology 92, 509-519.

Mason, J., Lamand, M., Tressol, J. C. \& Lab. C. (1978). Annals of Veterinary Research 9, 577-586.

Mason, J., Woods, M. \& Poole, D. B. R. (1986). Research in Veterinary Science 41, 108-113.

Mills, C. F., Bremner, I., El-Gallad, T. T., Dalgarno, A. C. \& Young, D. W. (1978). In Trace Element Metabolism in Man and Animals, pp. 150-158 [M. Kirchgessner, editor]. Weinhenstephan: Arbeitskreis für Tierernahrungsforshung.

Smith, B. S. W. \& Wright, H. (1975). Journal of Comparative Pathology 85, 299-305.

Walshe, J. M. (1986). In Orphan Diseases/Orphan Drugs, pp. 76-85 [I. H. Scheinberg and J. M. Walshe, editors]. Manchester: Manchester University Press.

Wang, Z. Y., Poole, D. B. R. \& Mason, J. (1986). Proceedings of the XIVth World Congress on Diseases of Cattle, pp. 845-849, [P. J. Hartigan and M. L. Monaghan, editors]. Dublin: Irish Cattle Veterinary Association.

Wang, Z. Y., Poole, D. B. R. \& Mason, J. (1988). Journal of Inorganic Biochemistry (In the Press).

Woods, M. \& Mason, J. (1987). Journal of Inorganic Biochemistry 30, 261-272. 